\title{
PENINGKATAN AKTIVITAS SISWA MELALUI PENDEKATAN MATEMATIKA REALISTIK PADA MATERI KESEBANGUNAN DI KELAS IX B SMP NEGERI 1 SAMALANTAN
}

\author{
J.Mujiarso \\ Guru SMPN 1 Samalantan, Kabupaten Bengkayang \\ email: mujiarso2910@gmail.com
}

\begin{abstract}
The aim of this research was to improve students' learning activities through realistic mathematical approaches in class IX B Junior High School Negeri 1 Samalantan in academic year of 2014/2015. The form of this research was classroom action research (CAR). The subjects in this study were the students of class IX B consisting of 34 students. The instrument of this research used the observation sheet and field notes. The results showed that an increase in the activity after the students were given a realistic mathematical approach on the material similarity. Based on the analysis of the data obtained the increased activity of the students at $11.776 \%$ after implementation realistic mathematics approach in two cycles of the action. Students' activities in asking questions increased by 13.7\%. Students' activities in answering questions increased from $75.49 \%$ to $79.4 \%$. While the activity of students in a discussion group increased by $9.81 \%$.
\end{abstract}

Key words: Students' activities, realistic mathematics approach, similarity.

Pembelajaran dalam konteks mempersiapkan sumber daya manusia abad 21 mengacu pada konsep belajar yang memberi pengalaman pada peserta didik seperti yang dicanangkan UNESCO yaitu "Learning to do, learning to know, learning to be, and learning to live together" (dalam Poedjiadi, 2005). Siswa harus diberdayakan agar mau dan mampu berbuat untuk memperkaya pengalaman belajarnya (learning to do) dengan meningkatkan interaksi dengan lingkungan fisik dan sosialnya, sehingga mampu membangun pemahaman dan pengetahuannya terhadap dunia di sekitarnya (learning to know). Diharapkan hasil interaksi dengan lingkungannya dapat membangun pengetahuan dan kepercayaan diri dan sekaligus membangun jati diri (learning to be). Kesempatan berinteraksi dengan berbagai individu yang bervariasi akan membentuk kepribadian dalam memahami kemajemukan, sehingga melahirkan sikap-sikap positif dan toleran terhadap keanekaragaman dan perbedaan (learning to live together).

Dengan demikian, dalam proses pembelajaran idealnya siswa terlibat secara aktif dalam proses pembelajaran. Pembelajaran yang dilakukan tidak hanyapeserta didik agar mampu berpikir logis, analitis, sistematis, kritis, dan kreatif, serta kemampuan bekerjasama. Sehingga pada proses pembelajaran matematika, keterampilan berfikir dan kerjasama antar siswa dapat dilatihkan melalui proses 
pembelajaran yang melibatkan siswa secara aktif. Siswa yang secara aktif membangun atau mengkonstruksi pengetahuannya sendiri. Agar siswa dapat aktif dalam proses pembelajaran guru sebagai fasilitator hendaknya menyediakan pengalaman belajar yang dapat membantu siswa mengembangkan seluruh potensi pada dirinya. Siswa juga dapat membangun pengetahuannya melalui kerjasama dengan teman sebayanya melalui bimbingan guru. Menurut Saleh (2012), guru perlu memperhatikan dan menumbuh kembangkan daya imajinasi dan rasa ingin tahu siswa, juga siswa harus dibiasakan untuk mendapat kesempatan bertanya dan berpendapat sehingga dalam proses belajar matematika tersebut siswa merasa bahwa matematika lebih bermakna. Jika siswa telah memiliki kebermaknaan matematika, harapan selanjutnya akan terbentuk rasa ingin tahu dan kecintaan siswa terhadap matematika.

Salah satu faktor penting yang dapat mempengaruhi belajar anak adalah apa yang telah diketahuinya, yaitu berupa pengetahuan awal (Novak, 1985). Pengetahuan awal yang telah dimiliki oleh anak akan berkembang secara optimal bila diikuti dengan ketepatan pemanfaatannya dalam hal menerima konsep baru. Namun selama ini proses pembelajaran matematika di SMP Negeri 1 Samalantan khususnya di kelas IX B, guru biasanya melakukan proses pembelajaran dengan urutan sajian pembelajaran matematika dengan mengajarkan teori/definisi/teorema/konsep-konsep terlebih dahulu selanjutnya guru memberikan contoh-contoh, setelah itu siswa diberikan latihan soal. Pada proses pembelajaran guru cenderung masih kurang menghadirkan masalah yang terkait dengan kehidupan seharihari di awal pembelajaran. Kaitan dengan masalah atau aplikasi dalam kehidupan sehari-hari diberikan di akhir pelajaran. Pembelajaran yang demikian mengakibatkan aktivitas siswa hanya meniru yang diajarkan guru, tanpa terlibat aktif menemukan rumus/pengertian sehingga siswa cenderung pasif. Aktivitas siswa hanya membaca, menulis, dan mengerjakan soal-soal latihan secara mandiri atau kelompok namun belum semua siswa yang terlibat. Siswa sudah pernah diberi kesempatan untuk memecahkan masalah seharihari sebagai penerapan dari konsepkonsep yang ditemukan namun hanya $10 \%$ siswa saja yang terlibat aktif.

Berdasarkan hasil observasi pada tanggal 17 Juli 2014 hanya $14,3 \%$ siswa yang bertanya, $28,8 \%$ menjawab, $45,7 \%$ mengerjakan tugas. Selain itu bentuk-bentuk soal latihan yang di kembangkan guru cenderung masih kurang kontekstual. Salah satu pendekatan dalam pembelajaran matematika yang menjadikan masalah-masalah realistik dan kontekstual dengan kehidupan siswa sebagai acuan pembelajaran adalah pendekatan matematika realistik. Pembelajaran matematika realistik Menurut Zainurie (dalam Soviawati, 2011) adalah pembelajaran matematika sekolah yang dilaksanakan dengan menempatkan realitas dan pengalaman siswa sebagai titik awal pembelajaran. Masalah-masalah realistik digunakan sebagai sumber munculnya konsepkonsep matematika atau pengetahuan matematika formal. Pembelajaran matematika realistik di kelas 
berorientasi pada karakteristikkarakteristik Realistic Mathematics Education (RME), sehingga siswa mempunyai kesempatan untuk menemukan kembali konsep-konsep matematika atau pengetahuan matematika formal. Selanjutnya, siswa diberi kesempatan mengaplikasikan konsep-konsep matematika untuk memecahkan masalah sehari-hari atau masalah dalam bidang lain. Mengaitkan pengalaman kehidupan nyata anak dengan ide-ide matematika dalam pembelajaran di kelas penting dilakukan agar pembelajaran bermakna (Soedjadi, 2000; Price, 1996; Zamroni, 2000 dalam Soviawati, 2011).

Treffers (dalam Zainurie, 2007) menyebutkan karakteristik RME antara lain adalah (a) menggunakan konteks dunia nyata, yang menjembatani konsep-konsep matematika dengan pengalaman anak sehari-hari; (b) menggunakan modelmodel (matematisasi), artinya siswa membuat model sendiri dalam menyelesaikan masalah; (c) menggunakan produksi dan konstruksi, dengan pembuatan produksi bebas siswa terdorong untuk melakukan refleksi pada bagian yang mereka anggap penting dalam proses belajar; (d) menggunakan interaksi, secara eksplisit bentuk-bentuk interaksi yang berupa negosiasi, penjelasan, pembenaran, setuju, tidak setuju, pertanyaan atau refleksi digunakan untuk mencapai bentk formal dari bentuk-bentuk informal siswa; dan (e) menggunakan keterkaitan, dalam mengaplikasikan matematika, biasanya diperlukan pengetahuan yang lebih kompleks dan tidak hanya aritmatika, aljabar, atau geometri tetapi juga bidang lain.

Menurut Gravemeijer (dalam Zubainur, 2012) terdapat tiga prinsip utama dalam PMRI, yaitu (1) penemuan terbimbing dan bermatematika secara maju (guided reinvention and progressive mathematizartion), (2) reali (realty principle), dan (3) model pengembangan mandiri (selfdeveloped model). Prinsip penemuan terbimbing berarti siswa diberikan kesempatan untuk menemukan sendiri konsep matematika dengan menyelesaikan berbagai soal kontekstual. Soal kontekstual ini mengarahkan siswa membentuk konsep, menyusun model, menerapkan konsep yang telah diketahui, dan menyelesaikannya berdasarkan kaidah matematika yang berlaku (Treffers \& Goffree, 1985 (dalam Zubainur, 2012). Berdasarkan soal, siswa membangun model dari (model of) situasi soal (dalam Zubainur, 2012) bentuk formal atau tidak), kemudian menyusun model matematika untuk (model for) menyelesaikannya hingga siswa mendapatkan pengetahuan formal matematika.

Van de Henvel-Panhuizen (dalam Soviawati, 2011) mengungkapkan bahwa bila anak belajar matematika terpisah dari pengalaman mereka sehari-hari maka anak akan cepat lupa dan tidak dapat mengaplikasikan matematika. Agar siswa dapat menemukan konsepkonsep berdasarkan masalah nyata tersebut, siswa melakukan berbagai aktivitas belajar seperti aktivitas mental (memecahkan masalah), oral (presentasi, bertanya, menyanggah, mengemukakan pendapat), menulis, 
menggambar dan lain-lain. Dengan demikian, peneliti tertarik untuk menerapkan pendekatan matematika realistik untuk mengetahui peningkatan aktivitas belajar siswa di kelas IX B SMPN 1 Samalantan Tahun Pelajaran 2014/2015.

\section{Metode}

Penelitian ini dilaksanakan di kelas IX B SMP Negeri 1 Samalantan pada Tahun Pelajaran 2014/2015. Subjek penelitian tindakan ini sebanyak 34 orang siswa yang terdiri dari 18 siswa perempuan dan 16 siswa laki-laki. Penelitian ini merupakan Penelitian Tindakan Kelas (PTK). Alur dalam penelitian tindakan kelas menggunakan model spiral yang dikembangkan Hopkins meliputi perencanaan, tindakan, pengamatan dan refleksi. Data diperoleh dari aktivitas belajar siswa dan keterlaksanaan proses pembelajaran oleh guru. Teknik pengumpulan data yang digunakan adalah teknik non tes yang terdiri atas lembar obsevasi untuk mengukur aktivitas belajar siswa dan catatan lapangan. Validitas data dilakukan dengan teknik triangulasi yaitu dengan membandingkan data hasil pengamatan dengan catatan lapangan dan isi rekaman yang berkaitan dengan proses pembelajaran yang dilakukan oleh guru. Teknik analisis data pada penelitian ini menggunakan analisis kualitatif yang terdiri atas tiga alur kegiatan yaitu reduksi data, penyajian data, penarikan kesimpulan dan verifikasi data. Indikator kinerja Penelitian Tindakan Kelas ini pada penilaian ranah pengetahuan ditentukan sebesar KKM yaitu skor 60 dengan jumlah siswa yang tuntas sebesar $75 \%$. Aktivitas siswa minimal mencapai sebesar $75 \%$ kategori aktif pada akhir Siklus.

\section{Hasil dan Pembahasan}

1. Siklus I

Perencanaan tindakan pada

siklus I dilakukan dengan mempersiapkan RPP, RPP disusun berdasarkan pendekatan matematika realistik, menyusun lembar kerja siswa, lembar observasi aktivitas siswa dan lembar observasi guru. Kompetensi dasar pada pembelajaran ini yaitu: "Mengidentifikasi bangun-bangun yang sama dan sebangun (kongruen)". Pelaksanaan tindakan dilakukan tanggal 22 Agustus 2014 dalam 1 kali pertemuan. Alokasi waktu pelaksanaan tindakan siklus I selama $2 \times 40$ menit. Pelaksanaan Tindakan pada fase 1 (stimulation) guru menyampaikan salam dan mempersiapkan siswa belajar dengan mengatur tempat duduk siswa serta mengecek kehadiran siswa. Guru menyampaikan tujuan pembelajaran dan memotivasi siswa selanjutnya guru memberikan stimulasi berupa pertanyaan" Siapa yang memiliki handphone?" "dari mana sinyalnya?" ( siswa menjawab "dari tower"), "Berapa tinggi tower?" "Bagaimana mengukurnya?" kemudian guru memberikan permasalahan-permasalahan lainnya yang serupa. Pada fase ini muncul karakteristik PMR yaitu memahami masalah kontekstual.

Pada fase 2 yaitu tahap problem statement (pernyataan/ identifikasi masalah) guru membimbing siswa untuk 
merumuskan jawaban sementara berdasarkan pertanyaan yang sudah di rancang siswa, pada fase 3 data collection (pengumpulan data), ketika eksplorasi berlangsung guru juga memberi kesempatan kepada para siswa untuk mengumpulkan informasi sebanyak-banyaknya yang relevan dengan melakukan pengamatan dan pengukuran secara langsung terhadap objek seperti mengukur panjangnya tiang bendera, mengukur jarak pada peta dan lain-lain, pada fase ini guru membentuk kelompok belajar yaitu 1 kelompok 4-5 orang, selanjutnya membagikan LKS untuk masing-masing kelompok. Pada fase 2 dan 3 muncul karakteristik PMR yaitu penggunaan konteks nyata dan adanya interaksi. Masalah nyata yang digunakan juga memiliki keterkaitan dengan mata pelajaran lain yaitu IPS yang berhubungan dengan skala (jarak pada peta).

Pada fase 4 data processing (pengolahan data), guru mengarahkan siswa untuk menghitung dan menafsirkan hasil pengamatan serta pengukuran sehingga siswa dapat menemukan konsep. Pada fase ini muncul karakteristik PMR yaitu menggunakan model untuk menyelesaikan masalah. Pada fase 5 verifikasi (verification) guru membimbing siswa untuk mengecek kembali apakah hipotesis atau jawaban sementara siswa terbukti atau tidak. Fase 6 generalisasi (generalization), siswa dibimbing untuk menyimpulkan berdasarkan hasil pengamatan dan pengukuran. Selanjutnya dilakukan kegiatan penutup.

Observasi

dilakukan selama pembelajaran berlangsung. Pengamatan terhadap aktivitas siswa dan guru dilakukan oleh satu orang pengamat dengan hasil sebagai berikut.

Tabel 1. Jumlah dan Persentase Siswa Pada Kategori Aktivitas Sangat aktif dan aktif.

\begin{tabular}{lc}
\hline Aspek & Siklus 1 \\
\hline Jumlah siswa & 30 \\
\hline Persentase & $88,24 \%$ \\
\hline
\end{tabular}

Berdasarkan tabel di atas, jumlah siswa yang aktif sudah mencapai indikator kinerja. Hasil observasi aktivitas siswa per aspek dapat dilihat pada tabel berikut.

Tabel 2. Persentase Aktivitas Siswa per Aspek Pengamatan Siklus 1.

\begin{tabular}{clc}
\hline No & \multicolumn{1}{c}{$\begin{array}{c}\text { Aspek } \\
\text { pengamatan }\end{array}$} & $\begin{array}{c}\text { Persentase } \\
(\%)\end{array}$ \\
\hline 1 & $\begin{array}{l}\text { Mengajukan } \\
\text { pertanyaan }\end{array}$ & 67,65 \\
\hline 2 & $\begin{array}{l}\text { Menjawab } \\
\text { pertanyaan }\end{array}$ & 75,49 \\
\hline 3 & $\begin{array}{l}\text { Berdiskusi } \\
\text { kelompok }\end{array}$ & 78,43 \\
\hline
\end{tabular}

Berdasarkan tabel di atas, aktivitas tertinggi yaitu melakukan diskusi kelompok sebesar 78,43\%, kemudian aktivitas terendah yaitu mengajukan pertanyaan sebesar 67,65\%. Berdasarkan hasil observasi, kolaborasi dengan teman sejawat pada mata pelajaran matematika ini didapatkan beberapa temuan dan rekomendasi. Pada siklus I pembelajaran menggunakan pendekatan matematika realistik terdapat 
beberapa kekurangan sehingga perlu perbaikan untuk siklus berikutnya. Temuan- temuan pada siklus I yaitu masih ada kelompok siswa yang masih rendah pada intensitas bertanya dan menjawab serta diskusi kelompoknya yaitu kelompok 2. Berdasarkan temuan di atas, diberikan rekomendasi pada pembelajaran selanjutnya pada siklus 2. Guru di sarankan dapat melakukan pembimbingan pada kelompok 2 lebih intensif lagi agar semua anggota kelompok dapat melakukan diskusi, bertanya, dan menjawab dengan intensitas yang maksimal.

2. Siklus II

Perencanaan siklus II
dengan materi kesebangunan.
Kompetensi dasar $r$ pada
pembelajaran ini $r$ yaitu:
Mengidentifikasi sifat-sifat dua
segi-tiga sebangun dan kongruen.
Perencanaan tindakan pada
siklus II dilakukan dengan
mempersiapkan RPP, RPP disusun
berdasarkan pendekatan
matematika realistik, menyusun
lembar kerja siswa, lembar
observasi aktivitas siswa dan
lembar observasi guru.
Pelaksanaan tindakan dilakukan
tanggal 29 Agustus 2014 dalam 1
kali pertemuan. Alokasi waktu
pelaksanaan tindakan siklus I
selama 2x40 menit. Pelaksanaan
Tindakan pada fase 1 (stimulation)
guru menyampaikan salam dan
mempersiapkan siswa belajar
dengan mengatur tempat duduk
siswa serta mengecek kehadiran
siswa. Guru menyampaikan tujuan
pembelajaran dan memotivasi
siswa. Selanjutnya raru
memberikan stimulasi dengan

menunjukkan dua buah segitiga dan menanyakan kepada siswa "apakah kedua segitiga tersebut sebangun?".

Pada fase 2 yaitu tahap problem statement (pernyataan/ identifikasi masalah) guru membimbing siswa untuk merumuskan jawaban sementara berdasarkan pertanyaan yang sudah di rancang siswa. Pada fase 3 data collection (pengumpulan data) ketika eksplorasi berlangsung guru juga memberi kesempatan kepada para siswa untuk mengumpulkan informasi sebanyak-banyaknya yang relevan dengan melakukan pengamatan dan pengukuran secara langsung terhadap objek seperti membuat segitiga dan mengukur sisi-sisinya untuk membuktikan dua segitiga yang sebangun, pada fase ini guru sebelumnya membentuk kelompok belajar seperti pada siklus 1 yaitu 1 kelompok terdiri dari 4-5 orang selanjutnya membagikan LKS untuk masing-masing kelompok. Pada fase 2 dan 3 muncul karakteristik PMR yaitu penggunaan konteks nyata dan adanya interaksi.

Pada fase 4 data processing (pengolahan data), guru mengarahkan siswa untuk menghitung dan menafsirkan hasil pengamatan serta pengukuran terhadap segitiga sehingga siswa dapat menemukan konsep dua segitiga yang sebangun. Pada fase ini muncul karakteristik PMR yaitu menggunakan model untuk menyelesaikan masalah. Pada fase 5 (verification) guru membimbing siswa untuk mengecek kembali apakah hipotesis atau jawaban 
sementara siswa terbukti atau tidak. Pada fase 6 generalization siswa dibimbing untuk menyimpulkan berdasarkan hasil pengamatan dan pengukuran. Selanjutnya dilakukan kegiatan penutup.

Observasi dilakukan selama pembelajaran berlangsung. Pengamatan terhadap aktivitas siswa dan guru dilakukan oleh satu orang pengamat dengan hasil sebagai berikut.

Tabel 3. Jumlah dan Persentase Siswa Pada Kategori Aktivitas Sangat aktif dan aktif

\begin{tabular}{lc}
\hline Aspek & Siklus 2 \\
\hline Jumlah siswa & 34 \\
\hline Persentase & $100 \%$ \\
\hline
\end{tabular}

Berdasarkan tabel di atas, jumlah siswa yang aktif sudah mencapai indikator kinerja. Hasil observasi aktivitas siswa per aspek dapat dilihat pada Tabel 4. Berdasarkan Tabel 4, aktivitas tertinggi yaitu melakukan diskusi kelompok sebesar 88,24\%. Berdasarkan hasil observasi, kolaborasi dengan teman sejawat pada mata pelajaran matematika ini, didapatkan beberapa temuan. Temuan- temuan pada siklus II yaitu pada semua kelompok siswa, intensitas bertanya dan menjawab serta diskusi kelompoknya sudah meningkat. Proses pembelajaran yang dilaksanakan guru sudah sesuai dengan RPP. Berdasarkan alokasi waktu yang dibutuhkan dirasa masih kurang, karena siswa masih ada yang terlambat mengumpulkan tugas karena kekurangan waktu.

Tabel 4. Persentase Aktivitas Siswa per Aspek Pengamatan Siklus 1.

\begin{tabular}{clc}
\hline No & $\begin{array}{l}\text { Aspek } \\
\text { pengamatan }\end{array}$ & $\begin{array}{c}\text { Persentase } \\
(\%)\end{array}$ \\
\hline 1 & $\begin{array}{l}\text { Mengajukan } \\
\text { pertanyaan }\end{array}$ & 81,37 \\
\hline 2 & $\begin{array}{l}\text { Menjawab } \\
\text { pertanyaan }\end{array}$ & 79,41 \\
\hline 3 & $\begin{array}{l}\text { Berdiskusi } \\
\text { kelompok }\end{array}$ & 88,24 \\
\hline
\end{tabular}

Perbandingan dan selisih hasil observasi aktivitas siswa antara siklus 1 dan siklus 2 dapat dilihat pada Tabel 5 dan Tabel 6.

Tabel 5. Jumlah dan persentase aktivitas siswa siklus 1 dan siklus 2.

\begin{tabular}{lccc}
\hline Aspek & Siklus 1 & Siklus 2 & Selisih \\
\hline Jumlah siswa & 30 & 34 & 4 \\
\hline Persentase & $88,24 \%$ & $100 \%$ & $11,76 \%$
\end{tabular}

Tabel 6. Perbandingan Persentase Aktivitas Siswa per Aspek Pengamatan antara Siklus 1 dan Siklus 2.

\begin{tabular}{llcc}
\hline No & Aspek pengamatan aktivitas & Siklus 1 & Siklus 2 \\
\hline 1 & Mengajukan pertanyaan & 67,65 & 81,37 \\
\hline 2 & Menjawab pertanyaan & 75,49 & 79,41 \\
\hline 3 & Diskusi kelompok & 78,43 & 88,24 \\
\hline
\end{tabular}

Berdasarkan hasil pengamatan pada akhir siklus II keaktifan siswa sudah mencapai $100 \%$ tergolong kategori aktif dan sangat aktif. 
Peningkatan keaktifan dari siklus 1 ke siklus 2 sebesar $11,76 \%$. Pada siklus 1 sudah menunjukkan tercapainya indikator kinerja, namun tetap dilanjutkan ke siklus 2 karena ingin membuktikan bahwa pendekatan matematika realistik sebagai faktor yang memberikan pengaruh terhadap aktivitas siswa tersebut. Keterlaksanaan proses pembelajaran sudah mencapai $100 \%$ pada siklus 1 dan siklus 2. Pembelajaran dengan menerapkan pendekatan matematika realistik ini meningkatkan beberapa aspek aktivitas yang diamati yaitu mengajukan pertanyaan, menjawab pertanyaan, dan diskusi kelompok. Aspek pengamatan pertama yaitu mengajukan pertanyaan dapat dilihat pada tabel 6 .

Pada siklus 1 aktivitas mengajukan pertanyaan sebesar $67,65 \%$, pada siklus kedua mengalami peningkatan hingga sebesar $81,37 \%$. Pada kegiatan pembelajaran siswa melakukan pengamatan secara langsung terhadap objek pengamatan, selain itu juga siswa melakukan pengukuran secara langsung. Kegiatan pengamatan dan pengukuran yang dilakukan siswa secara langsung dapat membangkitkan rasa ingin tahu siswa, melalui aktivitas bertanya. Kegiatan bertanya yang dilakukan siswa terkait hasil pengamatan yang belum jelas, selain itu siswa juga menanyakan mengenai bagaimana siswa dapat melakukan perhitungannya.

Pertanyaan-pertanyaan yang diajukan siswa merupakan pertanyaan-pertanyaan berupa fakta dan prosedur yang terkait hasil pengamatan pada saat siswa memahami masalah-masalah kontekstual terkait dengan materi kesebangunan. Selain itu juga siswa mengajukan pertanyaan pada saat siswa melakukan diskusi dan presentasi mengenai hasil pengamatan. Masalah-masalah nyata yang dekat dengan kehidupan seharihari yang digunakan dalam pembelajaran juga dapat memotivasi siswa belajar sehingga siswa dapat terlibat aktif dalam pembelajaran.

Pada aspek pengamatan yang kedua yaitu menjawab pertanyaan, pada siklus 1 aktivitas ini sebesar $75,49 \%$, sedangkan pada siklus 2 sebesar 79,41\%. Peningkatan aktivitas menjawab pertanyaan seiring dengan peningkatan aktivitas bertanya. Dalam proses siswa mengkonstrusi pengetahuannya, siswa saling bertanya dengan anggota kelompoknya, sehingga aktivitas menjawab pertanyaan juga semakin meningkat. Jawaban pertanyaan yang diberikan siswa dalam rangka siswa membangun konsep antara lain berupa penjelasan, kemudian pernyataan setuju atau tidak setuju antar anggota kelompok. Hal ini merupakan salah satu karakteristik pendekatan matematika realistik yaitu interaktif. Menurut Gravemeijer (dalam Windayana, 2007), pada saat siswa mengemukakan skema pembentukan model dalam interaksi antara siswa dengan siswa dan siswa dengan guru merupakan bagian penting dalam matematika realistik. Bentuk interaksi yang akan terjadi dalam pembelajaran di antaranya adalah negosiasi, penjelasan, pembenaran, setuju, tidak setuju, pertanyaan, atau refleksi.

Pada aktivitas diskusi kelompok siklus 1 persentase aktivitas siswa sebesar $78,43 \%$ pada siklus 2 terjadi peningkatan hingga 
mencapai $88,24 \%$. Pada saat diskusi kelompok siswa belajar dalam konteks sosial. Siswa belajar dalam suasana kebersamaan, saling berbagi dan saling mengadopsi model yang terbaik sebagai hasil proses dari kegiatan pemecahan masalah kontekstual sebagai sumber inspirasi dalammengkonstruk pengetahuan matematika formal. Hal tersbut terlihat dari hasil pekerjaan siswa pada lembar kerja siswa. Siswa sudah dapat memecahkan permasalahan dan menemukan konsep-konsep yang sesuai dengan teori. Melalui bimbingan guru, siswa dapat saling bekerjasama berbagi tugas dengan anggota kelompoknya. Pembelajaran yang demikian melatih siswa untuk menemukan sendiri konsep kesebangunan, sehingga pembelajaran dapat bermakna.

\section{Simpulan dan Saran}

Berdasarkan hasil penelitian, disimpulkan bahwa:

1. Aktivitas belajar siswa pada siklus 1 sebesar 88, 24\%, sedangkan siklus II sebesar $100 \%$, sehingga terjadi peningkatan aktivitas belajar siswa sebesar 11, 76\%.

2. Keterlaksanaan Proses pembelajaran menggunakan pendekatan matematika realistik sebesar $100 \%$ yaitu dengan karakteristik memunculkan masalah-masalah kontekstual, menggunakan model-model (matematisasi), menggunakan produksi dan konstruksi, menggunakan interaksi, dan menggunakan keterkaitan (intertwinment).

Berdasarkan keterbatasan yang terjadi pada pelaksanaan penelitian dapat disarankan bahwa pembelajaran dengan menggunakan pendekatan matematika realistik dapat diterapkan untuk materi bangun ruang, statistika, dan lain-lain dengan memperhatikan pengelolaan waktu dengan baik. Pada penelitian selanjutnya dapat di tinjau kreaktifitas dan minat belajar siswa.

\section{Daftar Pustaka}

Hopkins, D. 2011. Panduan Guru Penelitian Tindakan Kelas Edisi Ke-4: A Teacher's Guide To Classroom Research). Yogyakarta: Pustaka Pelajar.

Novak and Gowin. 1985. Learning How To Learn. Cambridge: Cambridge University Press.

Poedjiadi, A. 2005. Model Pembelajaran Sains Teknologi Masyarakat pada Pendidikan Formal. Hal 15-19. Prosiding Seminar Nasional Pendidikan IPA. Bandung.

Saleh, M. 2012. Pembelajaran Kooperatif Dengan Pendekatan Pendidikan Matematika Realistic (PMR). Jurnal Pendidikan Serambi Ilmu Vol. 13 No. 2 September 2012 (diakses 4 juli 2014)

Soviawati, E. 2011. Pendekatan Matematika Realistik (PMR) untuk Meningkatkan Kemampuan Berfikir Siswa di Tingkat Sekolah Dasar.(Online). http://jurnal. upi.edu/file/9-Evi_Soviawatiedit.pdf (di akses 5 juli 2014)

Windayana, H. 2007. Pembelajaran Matematika Realistik dalam Meningkatkan Kemampuan 
10 Jurnal Pendidikan Matematika dan IPA Vol. 5. No. 1. Januari 2014: 1-10

Berpikir Logis, Kreatif, dan Kritis, Serta Komunikasi Matematik Siswa Sekolah Dasar. Jurnal Pendidikan Dasar. No. 8 Oktober 2007.
Zubainur, CM. 2012. Penerapan Pendekatan Matematika Realistik Dalam Mengkonstruksi Algoritma Perkalian Siswa SD. Jurnal Pendidikan Serambi Ilmu Vol.13 No. 2 September 2012. 